\title{
Six thinking hats as a creative approach in managing meetings in hospitals
}

\author{
Eman Salman Taie', Ahmad A. El kamel² \\ 1. Nursing Administration Department, Faculty of Nursing, Helwan University, Cairo, Egypt. 2. Faculty of Veterinary \\ Medicine, Assiut University, Assiut, Egypt.
}

Correspondence: Eman Salman Taie, Head of Nursing Administration Department. Address: Nursing Administration Department, Faculty of Nursing, Helwan University. Cairo, Egypt. Email: dr_emys@hotmail.com

Received: May 2, 2013

DOI : 10.5430/jnep.v3n9p187

\begin{abstract}
Background: Meeting is a purposeful gathering of people, a goal oriented work session, a productive use of communal time and a cooperative group effort. Six thinking hats approach aims to encourage parallel thinking, full-spectrum thinking and to separate ego from performance.
\end{abstract}

Aim: The present study aims to explore the effect of using six thinking hats in managing meetings effectively.

Methods: It is a quasi-experimental study. The study was conducted in Dar el-Shefaa hospital in Cairo, Misr University for Science and Technology teaching hospital and Cleopatra hospital. Subjects were composed of three groups. The first group was comprised quality management committee in the selected hospitals; the second group was infection Control committee and the third one was hospital administration members. Three types of Questionnaire formats were used (study sample's knowledge about criteria for effective meetings and six thinking hats and study sample's evaluation of meetings management) plus opinionnare format to elicit the study sample's opinion about application of six thinking hats in meetings post training.

Findings: The majority of the studied samples before awareness sessions demonstrated lack of knowledge about criteria of effective meeting and six thinking hats. As evident, most of them agreed upon items regarding using of six thinking hats in meetings post training. Finally, the majority of the studied hospitals had low score for meeting management before using of the six thinking and high score after using of them.

Conclusion: This study clearly showed lack of knowledge about criteria for effective meeting and six thinking hats in the majority of the study sample before the awareness sessions. Scores of the majority of study sample's evaluation of meeting management were low before using of six thinking hats. Finally, post training, most of them agreed that using of six thinking hats increases the effectiveness of meetings.

\section{Key words}

Meeting, Meeting management, Six thinking hats, Lateral thinking, Effective meeting 


\section{I ntroduction}

Meeting is a purposeful gathering of people, a goal oriented work session, a productive use of communal time and a cooperative group effort. It is a time to educate all parties about issues, a time to discuss pertinent concerns, a time for two-way communication, a time to resolve problem issues and a time to instill an ethic. It is actually not a waste of everybody's time, an open time for other than safety discussions, a gripe session about working conditions, a formality because it is required and an arena to embarrass or shame people ${ }^{[1]}$. Meetings are a requisite tool for coordinating groups and teams of people, be it a steering committee or a board of directors. If people do not effectively make use of each other's time then people feel poorly utilized and it is a waste of the our single greatest non-renewable resource "time". An efficiently organized a meeting will have purpose, agenda and timeline. If these elements are missing, then the meeting will have a recipe for frustration ${ }^{[2-4]}$.

Meetings are a technique of bringing a group or team together to work for a common purpose. Effective meetings are an important aspect of making a group or team successful. Meetings allow the team to perform beyond the potential of each individual member. In meetings, the individual contributions are synergized to maximize the potential of the team. By bringing together members in meetings to pursue a common focus, better decisions, commitment, support, and implementation can result. The key is making the meeting effective ${ }^{[5,6]}$. A meeting should be conducted whenever a group of people need to get together to work toward a common focus. The focus could be to accomplish some action, or to provide some information. A meeting should only be conducted when there is a specific action needing to be accomplished by the group, or for passing information ${ }^{[2,3]}$.

Boardroom, casual and virtual meetings are regular features that aid discussions and decision-making. However, it is not necessary that all meetings are successful and end in the correct decisions. Often, meetings go haywire and become unfocused, leading to wastage of time and money. The research about meetings tends to confirm the anecdotal evidence. Council of Ontario Directors of Education ${ }^{[7]}$ suggested that over $50 \%$ of the time spent in meetings is unproductive. Furthermore, Mid-level managers spend in excess of $25 \%$ of their working hours in meetings. For senior executives it's even worse they spend in excess of $50 \%$ of their time in meetings. David Driskill ${ }^{[5]}$ found that, on average, the equivalent of $7 \%$ to $15 \%$ of personnel budgets are spent on person/time in meetings. Several tools like pre-planning and delegating tasks are used to ensure a smooth and successful meeting. However, none of these are foolproof. So, there is a need for a single process that will manage people and ideas while ensuring a focused meeting and quick decision-making. This process needs to be effective and practical. At the same time, it needs to be easy to comprehend and apply. The concept of "six thinking hats" is one such process that will help facilitate the same ${ }^{[1,5,8]}$.

The six thinking hats approach was invented by Edward de Bono early in 1980. The six hats represent six modes of thinking and are directions to think rather than labels for thinking. Hats are used proactively rather than reactively. It aims to encourage parallel thinking, full-spectrum thinking and to separate ego from performance ${ }^{[9]}$. Six thinking hats enhances performance rather than acting as an ego defense. Each person's unique thinking on the challenge is included which ensures a stronger solution is implemented, supported and is well thought out Mitez S. ${ }^{[17]}$. Six thinking hats is a concept involves using six, imaginary hats to aid decision-making. Each hat represents a role that its wearer needs to play. White Hat: The wearer of this hat has to play the role of gathering information. He has to delve into past records and present data, related to the topic of the meeting. Black Hat: The one who wears this hat has to play the role of opposition for every idea suggested. That is think of the negative aspects or everything that can go wrong while executing or making a decision. Yellow Hat: Contrary to the black hat, in this role, one has to look only at the positive side and the benefits of the issue under discussion. Red Hat: While wearing this imaginary hat, the person has to base his thoughts on an emotive or intuitive feeling about the project or decision. Green Hat: While donning the green hat, the wearer has to use his Edward de Bono and come up with out-of-the-box ideas. Blue Hat: The wearer of the green hat is the one that actually controls the proceedings of the meeting. That is he must ensure that the others stay focused, that the meeting goes on track and, finally, that the outcome is achieved ${ }^{[17-20]}$. 
According to the research about six thinking hats in the education field, De Bono ${ }^{[10]}$ merged Edward de Bono's six thinking hats into internet learning to train students in problem-solving, and the study indicated that including six thinking hats decreased the teaching load of the instructors and increased the quantitative and qualitative problem solving strategies of the students as compared with students not trained using six thinking hats. Wang, J. et al. ${ }^{[11]}$ compared 14 elementary students who took six thinking hats training with another 14 as a control group regarding the difference of problem-solving abilities. The study included 11 teaching units with six thinking hats, and results indicated that the experimental group had higher scores in explaining inference, casual thinking, and deciding solving methods as compared with the control groups. In nursing education, Lewis, D. ${ }^{[12]}$ first discussed and applied the De Bono, E. ${ }^{[13]}$ philosophy of six thinking hats in nursing clinics, administration, education, and research fields. Kenny, L. et al. ${ }^{[14-16]}$ applied six thinking hats as a reflection tool in the courses of hospice care, midwifery and surgery nursing to assist nursing students to think with diversity and creativity. In the study results of Karadag, M. et al. ${ }^{[16]}, 90.2 \%$ of nursing students reported that the course using six thinking hats helped them learn thinking from different perspectives; more than $80 \%$ of them expressed that the course helped them share different opinions and thoughts with others, using empathy and a holistic way of thinking about patients; and finally $75.5 \%$ of them indicated that the course helped them produce creative ideas.

\section{Significance of the study}

Many employees and staff members express dissatisfaction with meetings and complain that time spent in meetings is often nonproductive. Ever felt stuck in a meeting/discussion? Wanted to just walk out of a meeting room? Stuck for ages in a directionless meeting and no decisions are ever being made? We all have faced such a situation sometime in our life. Most of the times, when people enter meetings, they dread! Why? Because chances are that this meeting won't come to any conclusion and the discussion will be without any logical end. The only thing decided will be the "date" for the next meeting and most of every body's time will be a complete waste. For all of the previous reasons researchers decided to work on meeting management using creative technique as six thinking hats. So, when the researcher suggested using of this technique for the selected hospital, they to some extent realized the presence of this problem and accepted to work on it.

\section{Aim of the Study}

The present study aims to explore the effect of using six thinking hats in managing meetings effectively through:

1. Assess of study sample's knowledge about criteria of effective meetings and six thinking hats.

2. Increase study sample's knowledge about criteria of effective meetings and six thinking hats.

3. Conduct training for study sample on how to use six thinking hats in their meetings.

4. Determine study sample's opinion about using of six thinking hats in meetings post training.

5. Compare between study sample's evaluation of meeting management before $\&$ after using of six thinking hats.

\section{Research hypotheses}

It was hypnotized that using of six thinking hats may or may not improve the effectiveness of meetings, also, the study sample's perception about effective meeting before \& after using of six thinking hats may be will be the same.

\section{Subjects and methods}

\section{Research design}

It is a quasi- experimental study. 


\section{Study setting}

The study was conducted in Dar el-Shefaa hospital in Cairo (which is a therapeutic institution in Cairo under the ministry of health (MOH)), Misr University for Science and Technology teaching hospital and Cleopatra hospital (which is a private hospital).

\section{Subjects}

A convenient sample of 39 Quality Control Committee members, 37 of Infection Control Committee members and 134 of Administration members (see Table 1).

The study subjects consisted of three groups:

$\mathbf{1}^{\text {st }}$ group: All members of quality management committee in the selected hospitals.

$2^{\text {nd }}$ group: All members of infection control committee in the selected hospitals.

$3^{\text {rd }}$ group: Hospital administration members who attend quality and infection control meetings and other meetings in the hospital as (hospital manager, hospital assistant manager, nursing director, medical director, assistant nursing and medical directors, head of all departments in the hospital as head nurses, head physicians, head of financial department, head of human resources, Security, ....etc.

Table 1. Distribution of Study Samples According to Hospitals

\begin{tabular}{|c|c|c|c|c|c|c|}
\hline \multirow{2}{*}{ Hospital } & \multicolumn{2}{|c|}{$\begin{array}{l}\text { Quality Contro Committee } \\
(\mathrm{n}=39)\end{array}$} & \multicolumn{2}{|c|}{$\begin{array}{l}\text { Infection Control } \\
\text { Committee }(n=37)\end{array}$} & \multicolumn{2}{|c|}{$\begin{array}{l}\text { Administration members } \\
(\mathrm{n}=134)\end{array}$} \\
\hline & No. & $\%$ & No. & $\%$ & No. & $\%$ \\
\hline \multicolumn{7}{|l|}{ Teaching } \\
\hline $\begin{array}{l}\text { Misr University for Science and } \\
\text { Technology teaching hospital }\end{array}$ & 10 & 25.64 & 10 & 27.03 & 30 & 22.39 \\
\hline \multicolumn{7}{|c|}{ Therapeutic Institution under MOH } \\
\hline Dar el-Shefaa hospital in Cairo & 15 & 38.46 & 15 & 40.54 & 54 & 40.30 \\
\hline \multicolumn{7}{|l|}{ Private } \\
\hline Cleopatra hospital & 14 & 35.90 & 12 & 32.43 & 50 & 37.31 \\
\hline
\end{tabular}

\section{Tools of data collection}

Questionnaire format: three types were used; all were developed by researchers based on review of current literature. They were reviewed by experts in the related field, and modifications were made based on their suggestions. All of them were self-administered questionnaires. The first one was study sample's knowledge about effective meetings criteria questionnaire format. It included questions as before meeting what should take place, during meeting and after meeting which included ten items. While, the second one was study sample's knowledge about six thinking hats questionnaire format. It included questions as definition of six thinking hats, it benefits, how to use it...etc. which included eight items. Meanwhile, the third one was study sample's evaluation of meetings management format. It was used to evaluate meetings management before and after using of six thinking hats. It was used to assess organization and logistics of the meeting, participation, attitude, facilitator's role and if the meeting is valuable. It was included 30 items.

It was classified according to Likert Scale into three scales.

- $\quad$ Poor $=1$

- $\quad$ Fair $=2$ 
- $\quad$ Good $=3$

\section{Scoring of the meetings management questionnaire:}

The total score for this scale was 50. It was divided into three levels as follow:

a. Low score level: less than 30.

b. Moderate score level: ranged (31-37).

c. High score level: ranged (38-50).

Opinionnaire format: It was designed by researchers to elicit the study sample's opinion about application of six thinking hats in meetings post training. It was classified according to Likert Scale into three scales (Agree, Undecided and Disagree). It included fifteen items.

Pilot study: The aim of the pilot study was to test the practicability, (to test study feasibility and establish measurement scale reliability and validity). Also, to estimate the time needed to complete the tools. Researchers randomly selected 10 members of infection control committee, 12 members of quality management committee and 23 hospital administration members from the selected hospitals. To assess their knowledge about criteria of effective meeting and six thinking hats. The time needed to fulfill effective meetings criteria questionnaire format and six thinking hats questionnaire format ranged between (20-30) minutes. While, it was ranged between (30-45) minutes for evaluation format and finally for the opinionnaire format the time needed was ranged between (15-20) minutes. Collecting pilot study data lasts for one month. All of these subjects were included in the main study sample.

Field work: The field work of this study was executed in one year and two months. Data collection began on January first 2012 till March last 2013. Researchers started to assess study sample knowledge about criteria of effective meeting and six thinking hats. Using two questionnaire formats, they were self administered questionnaires. That was conducted in study sample's facility, after explaining to them the purpose of the study. The time needed to fulfill the questionnaire format for effective meeting criteria and six thinking hats questionnaire ranged between (20-30) minutes. While, it was ranged between (30-45) minutes for evaluation format. Based on results of the questionnaire formats, awareness sessions for study sample were conducted (five sessions for each hospital). After awareness sessions, study sample was re-assessed for their knowledge about effective meeting criteria and six thinking hats. The awareness sessions lasts for three months. Then, training for study sample on how to use six thinking hats in their meetings was given. This training program was conducted three times per week, one time per week in each hospital, and lasted for eight weeks. In each training no more than (15) members were included at a time. Finally, researchers used the opinionnaire format to determine study sample opinion about using of six thinking hats in meeting. The time needed for this format was ranged between (15-20) minutes. At the end, researchers gave study sample evaluation format again to evaluate meeting management after using of six thinking hats.

Administrative and ethical considerations: To carry out the study in the predetermined hospitals, letters containing the aim of the study were directed from the researcher's faculty of nursing to the hospitals' director to obtain their permission and help to conduct the study in their facility. Researchers then met hospitals directors and explained the purpose and methods of data collection for the study. Researchers also obtained study subjects' approval orally after explaining the purpose and method of data collection for the study. Confidentiality, anonymity and the right to withdraw from the study at any time were guaranteed.

\section{Statistical analysis}

SPSS statistical software package was used for data analysis. The $\mathrm{Z}$ test for comparison between two proportions as regards categorized data was used. The probability of error at .05 was considered significant, while at .01 and .001 was considered highly significant. 


\section{Results}

Table 2 displays study sample's knowledge about criteria for effective meeting before and awareness sessions. It was noticed that the majority of the studied sample before awareness sessions were lack of knowledge about criteria for effective meeting as a whole, first of all, regarding items which takes place before meeting as having an agenda, there is a

Table 2. Study Sample’s Knowledge About Criteria for Effective Meeting

\begin{tabular}{|c|c|c|c|c|c|c|c|c|c|c|c|c|c|}
\hline \multirow{3}{*}{$\begin{array}{l}\begin{array}{l}\text { Criteria for } \\
\text { effective } \\
\text { meeting }\end{array} \\
\text { Have an } \\
\text { Agenda (that } \\
\text { will lead to } \\
\text { meeting } \\
\text { outcomes) }\end{array}$} & \multicolumn{6}{|c|}{ Hospitals (Before awareness sessions) } & \multicolumn{6}{|c|}{ Hospitals (After awareness sessions) } & \multirow{3}{*}{$\boldsymbol{P}$} \\
\hline & \multicolumn{2}{|c|}{$\begin{array}{l}\text { Misr University } \\
\text { for Science and } \\
\text { Technology } \\
\text { teaching } \\
\text { hospital } \\
(n=50)\end{array}$} & \multicolumn{2}{|c|}{$\begin{array}{l}\text { Dar } \\
\text { el-Shefaa } \\
\text { hospital in } \\
\text { Cairo } \\
(\mathrm{n}=84)\end{array}$} & \multicolumn{2}{|c|}{$\begin{array}{l}\text { Cleopatra } \\
\text { hospital } \\
(n=76)\end{array}$} & \multicolumn{2}{|c|}{$\begin{array}{l}\text { Misr University } \\
\text { for Science and } \\
\text { Technology } \\
\text { teaching hospital } \\
(\mathrm{n}=50)\end{array}$} & \multicolumn{2}{|c|}{$\begin{array}{l}\text { Dar } \\
\text { el-Shefaa } \\
\text { hospital in } \\
\text { Cairo } \\
(\mathrm{n}=84)\end{array}$} & \multicolumn{2}{|c|}{$\begin{array}{l}\text { Cleopatra } \\
\text { hospital } \\
(n=76)\end{array}$} & \\
\hline & No. & $\%$ & No. & $\%$ & No. & $\%$ & No. & $\%$ & No. & $\%$ & No. & $\%$ & \\
\hline \multicolumn{14}{|c|}{ Before the meeting takes place } \\
\hline know & 12 & 24.00 & 10 & 11.90 & 14 & 18.42 & 44 & 88.00 & 79 & 94.05 & 70 & 92.11 & $<.001$ \\
\hline Do not Know & 38 & 76.00 & 74 & 88.10 & 62 & 81.58 & 6 & 12.00 & 5 & 5.95 & 6 & 7.89 & $<.001$ \\
\hline \multicolumn{14}{|c|}{ Defined meeting objectives, (define meeting outcomes; make sure outcomes are S.M.A.R.T) } \\
\hline know & 6 & 12.00 & 6 & 7.14 & 6 & 7.89 & 42 & 84.00 & 78 & 92.86 & 72 & 94.74 & $<.001$ \\
\hline Do not Know & 44 & 88.00 & 78 & 92.86 & 70 & 92.11 & 8 & 16.00 & 6 & 7.14 & 4 & 5.26 & $<.001$ \\
\hline \multicolumn{14}{|c|}{$\begin{array}{c}\text { Disseminate key information (outcomes, plan, key resources, location, time, etc) to participants at } \\
\text { least } 24 \text { hours in advance }\end{array}$} \\
\hline know & 7 & 14.00 & 8 & 9.52 & 9 & 11.84 & 46 & 92.00 & 80 & 95.24 & 74 & 97.37 & $<.001$ \\
\hline Do not Know & 43 & 86.00 & 76 & 90.48 & 67 & 88.16 & 4 & 8.00 & 4 & 4.76 & 2 & 2.63 & $<.001$ \\
\hline \multicolumn{14}{|c|}{ Meeting Execution } \\
\hline know & 2 & 4.00 & 4 & 4.76 & 4 & 5.26 & 43 & 86.00 & 76 & 90.48 & 71 & 93.42 & $<.001$ \\
\hline Do not Know & 48 & 96.00 & 80 & 95.24 & 72 & 94.74 & 7 & 14.00 & 8 & 9.52 & 5 & 6.58 & $<.001$ \\
\hline \multicolumn{14}{|c|}{ Apply the process techniques } \\
\hline know & 0 & 0.00 & 0 & 0.00 & 0 & 0.00 & 41 & 82.00 & 73 & 86.90 & 73 & 96.05 & $<.001$ \\
\hline Do not Know & 50 & 100.0 & 84 & 100.0 & 76 & 100.00 & 9 & 18.00 & 11 & 13.10 & 3 & 3.95 & $<.001$ \\
\hline \multicolumn{14}{|c|}{ Keeping the minutes of the meeting } \\
\hline know & 0 & 0.00 & 0 & 0.00 & 0 & 0.00 & 40 & 80.00 & 79 & 94.05 & 70 & 92.11 & $<.001$ \\
\hline Do not Know & 50 & 100.00 & 84 & 100.0 & 76 & 100.00 & 10 & 20.00 & 5 & 5.95 & 6 & 7.89 & $<.001$ \\
\hline \multicolumn{14}{|c|}{ Meeting Follow Up (after meeting--complete within 24 hrs) } \\
\hline \multicolumn{14}{|c|}{ Complete meeting documentation } \\
\hline know & 5 & 10.00 & 8 & 9.52 & 11 & 14.47 & 44 & 88.00 & 78 & 92.86 & 68 & 89.47 & $<.001$ \\
\hline Do not Know & 45 & 90.00 & 76 & 90.48 & 65 & 85.53 & 6 & 12.00 & 6 & 7.14 & 8 & 10.53 & $<.001$ \\
\hline \multicolumn{14}{|c|}{ Disseminate documentation to key stakeholders } \\
\hline know & 8 & 16.00 & 12 & 14.29 & 12 & 15.79 & 45 & 90.00 & 80 & 95.24 & 72 & 94.74 & $<.001$ \\
\hline Do not Know & 42 & 84.00 & 72 & 85.71 & 64 & 84.21 & 5 & 10.00 & 4 & 4.76 & 4 & 5.26 & $<.001$ \\
\hline
\end{tabular}

defined meeting objectives and disseminate key information (outcomes, plan, key resources, location, time, etc.) to participants at least 24 hours in advance. In the first item it was (76\%, 88.1\% \& 81.58\%), in the second item (88\%, 92.86\% \& $92.11 \%)$ while in the last one it was (86\%, $90.48 \%$ \& $88.16 \%)$. As regard post awareness sessions, the majority of the study sample was had enough knowledge about all items (88\%, 94.05\% \& 92.11\%), (84\%, 92.86 \& 94.74\%) and (92\%, $95.24 \% \& 97.37 \%$ ) respectively. Meanwhile, meeting execution (following the outlined activities on the agenda, apply the 
Table 3. Study Sample’s Knowledge About Six Thinking Hats

\begin{tabular}{|c|c|c|c|c|c|c|c|c|c|c|c|c|c|}
\hline \multirow{3}{*}{ Items } & \multicolumn{6}{|c|}{ Hospitals (Before awareness sessions \& training) } & \multicolumn{6}{|c|}{ Hospitals (After awareness sessions \& training) } & \multirow{3}{*}{$\boldsymbol{P}$} \\
\hline & \multicolumn{2}{|c|}{$\begin{array}{l}\text { Misr University } \\
\text { for Science and } \\
\text { Technology } \\
\text { teaching } \\
\text { hospital }(n=50)\end{array}$} & \multicolumn{2}{|c|}{$\begin{array}{l}\text { Dar el-Shefaa } \\
\text { hospital in } \\
\text { Cairo } \\
(\mathrm{n}=84)\end{array}$} & \multicolumn{2}{|c|}{$\begin{array}{l}\text { Cleopatra } \\
\text { hospital } \\
(n=76)\end{array}$} & \multicolumn{2}{|c|}{$\begin{array}{l}\text { Misr University } \\
\text { for Science and } \\
\text { Technology } \\
\text { teaching hospital } \\
(\mathrm{n}=50)\end{array}$} & \multicolumn{2}{|c|}{$\begin{array}{l}\text { Dar } \\
\text { el-Shefaa } \\
\text { hospital in } \\
\text { Cairo } \\
(n=84)\end{array}$} & \multicolumn{2}{|c|}{$\begin{array}{l}\text { Cleopatra } \\
\text { hospital } \\
(\mathrm{n}=76)\end{array}$} & \\
\hline & No. & $\%$ & No. & $\%$ & No. & $\%$ & No. & $\%$ & No. & $\%$ & No. & $\%$ & \\
\hline \multicolumn{14}{|c|}{ What is Parallel Thinking? } \\
\hline \multirow{2}{*}{$\begin{array}{l}\text { know } \\
\text { Do not } \\
\text { Know } \\
\end{array}$} & 0 & 0.00 & 0 & 0.00 & 0 & 0.00 & 45 & 90.00 & 78 & 92.86 & 71 & 93.42 & $<.001$ \\
\hline & 50 & 100.00 & 84 & 100.00 & 76 & 100.00 & 5 & 10.00 & 6 & 7.14 & 5 & 6.58 & $<.001$ \\
\hline \multicolumn{14}{|c|}{ What is Traditional Thinking? } \\
\hline \multirow{2}{*}{$\begin{array}{l}\text { know } \\
\text { Do not } \\
\text { Know }\end{array}$} & 0 & 0.00 & 0 & 0.00 & 0 & 0.00 & 43 & 86.00 & 79 & 94.05 & 74 & 97.37 & $<.001$ \\
\hline & 50 & 100.00 & 84 & 100.00 & 76 & 100.00 & 7 & 14.00 & 5 & 5.95 & 2 & 2.63 & $<.001$ \\
\hline \multicolumn{14}{|c|}{ What is Lateral Thinking? } \\
\hline \multirow{2}{*}{$\begin{array}{l}\text { know } \\
\text { Do not } \\
\text { Know }\end{array}$} & 0 & 0.00 & 0 & 0.00 & 0 & 0.00 & 44 & 88.00 & 78 & 92.86 & 73 & 96.05 & $<.001$ \\
\hline & 50 & 100.00 & 84 & 100.00 & 76 & 100.00 & 6 & 12.00 & 6 & 7.14 & 3 & 3.95 & $<.001$ \\
\hline \multicolumn{14}{|c|}{ What are six thinking hats } \\
\hline \multirow{2}{*}{$\begin{array}{l}\text { know } \\
\text { Do not } \\
\text { Know } \\
\end{array}$} & 0 & 0.00 & 0 & 0.00 & 0 & 0.00 & 42 & 84.00 & 75 & 89.29 & 71 & 93.42 & $<.001$ \\
\hline & 50 & 100.00 & 84 & 100.00 & 76 & 100.00 & 8 & 16.00 & 9 & 10.71 & 5 & 6.58 & $<.001$ \\
\hline \multicolumn{14}{|c|}{ Benefits of the Six Thinking Hats } \\
\hline \multirow{2}{*}{$\begin{array}{l}\text { know } \\
\text { Do not } \\
\text { Know }\end{array}$} & 0 & 0.00 & 0 & 0.00 & 0 & 0.00 & 43 & 86.00 & 79 & 94.05 & 73 & 96.05 & $<.001$ \\
\hline & 50 & 100.00 & 84 & 100.00 & 76 & 100.00 & 7 & 14.00 & 5 & 5.95 & 3 & 3.95 & $<.001$ \\
\hline \multicolumn{14}{|c|}{ How to use the Six Thinking Hats } \\
\hline \multirow{2}{*}{$\begin{array}{l}\text { know } \\
\text { Do not } \\
\text { Know }\end{array}$} & 0 & 0.00 & 0 & 0.00 & 0 & 0.00 & 42 & 84.00 & 79 & 94.05 & 71 & 93.42 & $<.001$ \\
\hline & 50 & 100.00 & 84 & 100.00 & 76 & 100.00 & 8 & 16.00 & 5 & 5.95 & 5 & 6.58 & $<.001$ \\
\hline \multicolumn{14}{|c|}{ Facilitator's Role } \\
\hline know & 0 & 0.00 & 0 & 0.00 & 0 & 0.00 & 45 & 90.00 & 77 & 91.67 & 72 & 94.74 & $<.001$ \\
\hline $\begin{array}{l}\text { Do not } \\
\text { Know }\end{array}$ & 50 & 100.00 & 84 & 100.00 & 76 & 100.00 & 5 & 10.00 & 7 & 8.33 & 4 & 5.26 & $<.001$ \\
\hline \multicolumn{14}{|c|}{ Participant's Role } \\
\hline know & 0 & 0.00 & 0 & 0.00 & 0 & 0.00 & 44 & 88.00 & 80 & 95.24 & 73 & 96.05 & $<.001$ \\
\hline $\begin{array}{l}\text { Do not } \\
\text { Know }\end{array}$ & 50 & 100.00 & 84 & 100.00 & 76 & 100.00 & 6 & 12.00 & 4 & 4.76 & 3 & 3.95 & $<.001$ \\
\hline
\end{tabular}

process techniques and keeping the minutes of the meeting). It was noticed that the majority of the studied sample before awareness sessions were lack of knowledge about all of the previous items (96\%, 95.24\% \& 94.74\%) and 100\% for second and third items. On the other hand, post awareness sessions, the highest percentage of them were aware of the previous items (86\%, 90.48\% \& 93.42\%), (82\%, 93.42\% \& 96.05\%) and (80\%, 94.05\% \& 92.11\%) respectively. Finally, meeting follow up (after meeting-complete within $24 \mathrm{hrs).} \mathrm{It} \mathrm{was} \mathrm{noticed} \mathrm{that} \mathrm{the} \mathrm{majority} \mathrm{of} \mathrm{the} \mathrm{studied} \mathrm{sample} \mathrm{before} \mathrm{awareness}$ sessions were lack of knowledge about its items (complete meeting documentation and disseminate documentation to key stakeholders) (90\%, 90.48\% and 85.53\%) respectively. While, regarding post awareness sessions, the majority of them 
were aware of the previous items (88\%, 92.86\% \& 89.47\%) and (90\%, 95.24\% and 94.74\%) respectively. There was a high significant $(p<.001)$ difference between them before and after awareness sessions regarding their knowledge about criteria for effective meeting.

As regards study sample's knowledge about six thinking hats, Table 3 illustrates that no one (100\%) of the studied sample before awareness sessions knew anything about all items of six thinking hats as (parallel thinking, traditional thinking, lateral thinking, six thinking hats, its benefits, how to use it, facilitator's role and participants' role). As evident, post awareness sessions, the majority of the study sample was had enough knowledge about six thinking hats items (90\%, 92.86\% \& 93.42\%), (86\%, 94.05\% \& 97.37\%), (88\%, 92.86\% \& 96.05\%), (84\%, 89.29\% \& 93.43\%), (90\%, 91.67\% \& 94.74\%) and (88\%, 95.24\% \& 96.05\%) respectively. There was a high significant $(p<.001)$ difference between them before and after awareness sessions regarding their knowledge about six thinking hats.

Concerning study sample's opinion about using of six thinking hats in meetings post training, Table 4 shows that the majority of the studied sample asserted that they agreed upon all of items $(1,2,4,5,7,8,9,10,11,15)$ as appeared in the table and all of them (100\%) agreed upon items (13 \& 14). On the other hand, the majority of them (90\%, 89.29\% \& 98.68\%), (86\%, \& 97.62\% \& 97.37\%) and (96\%, 92.86\% \& 100\%) respectively disagreed upon items (3, 6 \& 12). There was no significant $(p>.05)$ difference between all of the studied hospitals regarding their opinion of six thinking hats in meetings post training.

Table 4. Study Sample’s Opinion About Using of Six Thinking Hats in Meetings Post Training

\begin{tabular}{|c|c|c|c|c|c|c|c|c|}
\hline \multirow{2}{*}{\multicolumn{2}{|c|}{ Study sample's opinion Items }} & \multicolumn{2}{|c|}{$\begin{array}{l}\text { Misr University for } \\
\text { Science and Technology } \\
\text { teaching hospital } \\
(\mathrm{n}=50)\end{array}$} & \multicolumn{2}{|c|}{$\begin{array}{l}\text { Dar el-Shefaa } \\
\text { hospital in } \\
\text { Cairo }(n=84)\end{array}$} & \multicolumn{2}{|c|}{$\begin{array}{l}\text { Cleopatra } \\
\text { hospital } \\
(\mathrm{n}=76)\end{array}$} & \multirow[t]{2}{*}{$\boldsymbol{P}$} \\
\hline & & No. & $\%$ & $\mathbf{N}$ & $\%$ & No. & $\%$ & \\
\hline . & $\begin{array}{l}\text { It helped me produce creative ideas. } \\
\text { - } \quad \text { Agree } \\
\text { - } \quad \text { undecided } \\
\text { - } \quad \text { Disagree }\end{array}$ & $\begin{array}{l}44 \\
3 \\
3\end{array}$ & $\begin{array}{l}88.00 \\
6.00 \\
6.00\end{array}$ & $\begin{array}{l}76 \\
5 \\
3\end{array}$ & $\begin{array}{l}90.48 \\
5.95 \\
3.57\end{array}$ & $\begin{array}{l}72 \\
4 \\
0\end{array}$ & $\begin{array}{l}94.74 \\
5.26 \\
0.00\end{array}$ & $\begin{array}{l}>.05 \\
>.05 \\
>.05\end{array}$ \\
\hline . & $\begin{array}{l}\text { It made it easier for me to empathize with } \\
\text { the main meeting's purpose and } \\
\text { objectives. } \\
\text { - Agree } \\
\text { - Undecided } \\
\text { - Disagree }\end{array}$ & $\begin{array}{l}46 \\
2 \\
2\end{array}$ & $\begin{array}{l}92.00 \\
4.00 \\
4.00\end{array}$ & $\begin{array}{l}77 \\
5 \\
2\end{array}$ & $\begin{array}{l}91.67 \\
5.95 \\
2.38\end{array}$ & $\begin{array}{l}73 \\
2 \\
1\end{array}$ & $\begin{array}{l}96.05 \\
2.63 \\
1.32\end{array}$ & $\begin{array}{l}>.05 \\
>.05 \\
>.05\end{array}$ \\
\hline 3. & $\begin{array}{l}\text { Empathy turned into sympathy; it had a } \\
\text { negative effect on me. } \\
\text { - } \quad \text { Agree } \\
\text { - } \quad \text { Undecided } \\
\text { - } \quad \text { Disagree }\end{array}$ & $\begin{array}{l}4 \\
1 \\
45\end{array}$ & $\begin{array}{l}8.00 \\
2.00 \\
90.00\end{array}$ & $\begin{array}{l}5 \\
4 \\
75\end{array}$ & $\begin{array}{l}5.95 \\
4.76 \\
89.29\end{array}$ & $\begin{array}{l}0 \\
1 \\
75\end{array}$ & $\begin{array}{l}0.00 \\
1.32 \\
98.68\end{array}$ & $\begin{array}{l}>.05 \\
>.05 \\
>.05\end{array}$ \\
\hline 4. & $\begin{array}{l}\text { It helped me to be focused. } \\
\text { : } \quad \text { Agree } \\
\text { - } \quad \text { Undecided } \\
\text { - } \quad \text { Disagree }\end{array}$ & $\begin{array}{l}48 \\
2 \\
0\end{array}$ & $\begin{array}{l}96.00 \\
4.00 \\
0.00\end{array}$ & $\begin{array}{l}79 \\
4 \\
1\end{array}$ & $\begin{array}{l}94.05 \\
4.76 \\
1.19\end{array}$ & $\begin{array}{l}74 \\
2 \\
0\end{array}$ & $\begin{array}{l}97.37 \\
2.63 \\
0.00\end{array}$ & $\begin{array}{l}>.05 \\
>.05 \\
>.05\end{array}$ \\
\hline 5. & $\begin{array}{l}\text { It provided for sharing of different ideas } \\
\text { and thoughts. } \\
\text { - Agree } \\
\text { - Undecided } \\
\text { - Disagree }\end{array}$ & $\begin{array}{l}47 \\
3 \\
0\end{array}$ & $\begin{array}{l}94.00 \\
6.00 \\
0.00\end{array}$ & $\begin{array}{l}80 \\
2 \\
2\end{array}$ & $\begin{array}{l}95.24 \\
2.38 \\
2.38\end{array}$ & $\begin{array}{l}74 \\
2 \\
0\end{array}$ & $\begin{array}{l}97.37 \\
2.63 \\
0.00\end{array}$ & $\begin{array}{l}>.05 \\
>.05 \\
>0.05\end{array}$ \\
\hline 6. & $\begin{array}{l}\text { In particular the black hat activity } \\
\text { (negative) made me pessimistic. } \\
\text { - Agree } \\
\text { - Undecided } \\
\text { - Disagree }\end{array}$ & $\begin{array}{l}3 \\
4 \\
43\end{array}$ & $\begin{array}{l}6.00 \\
8.00 \\
86.00\end{array}$ & $\begin{array}{l}0 \\
2 \\
82\end{array}$ & $\begin{array}{l}0.00 \\
2.38 \\
97.62\end{array}$ & $\begin{array}{l}1 \\
1 \\
74\end{array}$ & $\begin{array}{l}1.32 \\
1.32 \\
97.37\end{array}$ & $\begin{array}{l}>.05 \\
>.05 \\
>.05\end{array}$ \\
\hline
\end{tabular}


Table 4. (Continued)

\begin{tabular}{|c|c|c|c|c|c|c|c|c|}
\hline \multirow{2}{*}{\multicolumn{2}{|c|}{ Study sample's opinion Items }} & \multicolumn{2}{|c|}{$\begin{array}{l}\text { Misr University for } \\
\text { Science and Technology } \\
\text { teaching hospital } \\
(\mathrm{n}=50)\end{array}$} & \multicolumn{2}{|c|}{$\begin{array}{l}\text { Dar el-Shefaa } \\
\text { hospital in } \\
\text { Cairo }(n=84)\end{array}$} & \multicolumn{2}{|c|}{$\begin{array}{l}\text { Cleopatra } \\
\text { hospital } \\
(n=76)\end{array}$} & \multirow[t]{2}{*}{$\boldsymbol{P}$} \\
\hline & & No. & $\%$ & $\mathbf{N}$ & $\%$ & No. & $\%$ & \\
\hline 7. & $\begin{array}{l}\text { It helped me detect differences in my } \\
\text { thoughts and helped me know myself. } \\
\text { Agree } \\
\text { - Undecided } \\
\text { Disagree }\end{array}$ & $\begin{array}{l}42 \\
4 \\
4\end{array}$ & $\begin{array}{l}84.00 \\
8.00 \\
8.00\end{array}$ & $\begin{array}{l}78 \\
4 \\
2\end{array}$ & $\begin{array}{l}92.86 \\
4.76 \\
2.38\end{array}$ & $\begin{array}{l}73 \\
2 \\
1\end{array}$ & $\begin{array}{l}96.05 \\
2.63 \\
1.32\end{array}$ & $\begin{array}{l}>.05 \\
>.05 \\
>.05\end{array}$ \\
\hline 8. & $\begin{array}{l}\text { It improved my thinking systems. } \\
\text { : Agree } \\
\text { : } \quad \text { Disagrec }\end{array}$ & $\begin{array}{l}47 \\
3 \\
0\end{array}$ & $\begin{array}{l}94.00 \\
6.00 \\
0.00\end{array}$ & $\begin{array}{l}81 \\
3 \\
0\end{array}$ & $\begin{array}{l}96.43 \\
3.57 \\
0.00\end{array}$ & $\begin{array}{l}75 \\
1 \\
0\end{array}$ & $\begin{array}{l}98.68 \\
1.32 \\
0.00\end{array}$ & $\begin{array}{l}>.05 \\
>.05 \\
>.05\end{array}$ \\
\hline 9. & $\begin{array}{l}\text { I learned to think about different aspects } \\
\text { of a subject. } \\
\text { : Agree } \\
\text { : } \quad \text { Undecided } \\
\text { - Disagree }\end{array}$ & $\begin{array}{l}47 \\
2 \\
1\end{array}$ & $\begin{array}{l}94.00 \\
4.00 \\
2.00\end{array}$ & $\begin{array}{l}80 \\
2 \\
2\end{array}$ & $\begin{array}{l}95.24 \\
2.38 \\
2.38\end{array}$ & $\begin{array}{l}74 \\
2 \\
0\end{array}$ & $\begin{array}{l}97.37 \\
2.63 \\
0.00\end{array}$ & $\begin{array}{l}>.05 \\
>.05 \\
>.05\end{array}$ \\
\hline 10. & $\begin{array}{ll}\text { It made me respect different ideas. } \\
: \quad \text { Agree } \\
: \quad \text { undecided } \\
\text { - } & \text { Disagree }\end{array}$ & $\begin{array}{l}45 \\
4 \\
1\end{array}$ & $\begin{array}{l}90.00 \\
8.00 \\
2.00\end{array}$ & $\begin{array}{l}79 \\
5 \\
0\end{array}$ & $\begin{array}{l}94.05 \\
5.95 \\
0.00\end{array}$ & $\begin{array}{l}73 \\
2 \\
1\end{array}$ & $\begin{array}{l}96.05 \\
2.63 \\
1.32\end{array}$ & $\begin{array}{l}>.05 \\
>.05 \\
>.05\end{array}$ \\
\hline 11. & $\begin{array}{l}\text { It helped me develop my creativity. } \\
\text { : } \quad \text { Agree } \\
\text { : } \quad \text { Undecided } \\
\text { Disagree }\end{array}$ & $\begin{array}{l}45 \\
3 \\
2\end{array}$ & $\begin{array}{l}90.00 \\
6.00 \\
4.00\end{array}$ & $\begin{array}{l}78 \\
4 \\
2\end{array}$ & $\begin{array}{l}92.86 \\
4.76 \\
2.38\end{array}$ & $\begin{array}{l}73 \\
3 \\
0\end{array}$ & $\begin{array}{l}96.05 \\
3.95 \\
0.00\end{array}$ & $\begin{array}{l}>.05 \\
>.05 \\
>.05\end{array}$ \\
\hline 12. & $\begin{array}{l}\text { Discussing the subject from six different } \\
\text { aspects was time consuming. } \\
\text { Agree } \\
\text { : Undecided } \\
\text { Disagree }\end{array}$ & $\begin{array}{l}2 \\
0 \\
48\end{array}$ & $\begin{array}{l}4.00 \\
0.00 \\
96.00\end{array}$ & $\begin{array}{l}4 \\
2 \\
78\end{array}$ & $\begin{array}{l}4.76 \\
2.38 \\
92.86\end{array}$ & $\begin{array}{l}0 \\
0 \\
76\end{array}$ & $\begin{array}{l}0.00 \\
0.00 \\
100.00\end{array}$ & $\begin{array}{l}>.05 \\
>0.05 \\
>0.05\end{array}$ \\
\hline 13. & $\begin{array}{l}\text { It increased my interest and motivation in } \\
\text { meetings. } \\
\text { : Agree } \\
\text { : } \quad \text { Undecided } \\
\text { Disagree }\end{array}$ & $\begin{array}{l}48 \\
2 \\
0\end{array}$ & $\begin{array}{l}96.00 \\
4.00 \\
0.00\end{array}$ & $\begin{array}{l}82 \\
2 \\
0\end{array}$ & $\begin{array}{l}97.62 \\
2.38 \\
0.00\end{array}$ & $\begin{array}{l}76 \\
0 \\
0\end{array}$ & $\begin{array}{l}100.00 \\
0.00 \\
0.00\end{array}$ & $\begin{array}{l}>.05 \\
>.05 \\
>.05\end{array}$ \\
\hline 14. & $\begin{array}{l}\text { It made me think critically (analyzing and } \\
\text { synthesizing the knowledge I had). } \\
\text { Agree } \\
\text { - Undecided } \\
\text { Disagree }\end{array}$ & $\begin{array}{l}46 \\
4 \\
0\end{array}$ & $\begin{array}{l}92.00 \\
8.00 \\
0.00\end{array}$ & $\begin{array}{l}80 \\
4 \\
0\end{array}$ & $\begin{array}{l}95.24 \\
4.76 \\
0.00\end{array}$ & $\begin{array}{l}76 \\
0 \\
0\end{array}$ & $\begin{array}{l}100.00 \\
0.00 \\
0.00\end{array}$ & $\begin{array}{l}>.05 \\
>.05 \\
>.05\end{array}$ \\
\hline 15. & $\begin{array}{l}\text { It helped me to work \& think in a team } \\
\text { (team building approach). } \\
\text { : Agree } \\
\text { : Undecided } \\
\text { Disagree }\end{array}$ & $\begin{array}{l}48 \\
2 \\
0\end{array}$ & $\begin{array}{l}96.00 \\
4.00 \\
0.00\end{array}$ & $\begin{array}{l}82 \\
2 \\
0\end{array}$ & $\begin{array}{l}97.62 \\
2.38 \\
0.00\end{array}$ & $\begin{array}{l}76 \\
0 \\
0\end{array}$ & $\begin{array}{l}100.00 \\
0.00 \\
0.00\end{array}$ & $\begin{array}{l}>.05 \\
>.05 \\
>.05\end{array}$ \\
\hline
\end{tabular}

Note. Not Significant $p>.05$

Significant $p<.05$

Highly significant $p<.01$

Table 5 displays study sample's evaluation of meeting management scores before \& after using of six thinking hats, it revealed that the majority of the studied hospitals had low score for meeting management before using of the six thinking hats (76\%, 94.05\% \& 92.11\%) respectively. Meanwhile, no one of them had high score. On the other hand, after using of six thinking hats, the majority of them had high score for managing meetings (86\%, 95.24\% \& 96.05\%) respectively and no one of them had low score. There was a high significant $(p<.001)$ difference between their scores for meeting management before and after using of six thinking hats. 
Table 5. Study Sample’s Evaluation of Meeting Management Scores Before \& After Using of Six Thinking Hats

\begin{tabular}{|c|c|c|c|c|c|c|c|c|c|c|c|c|c|}
\hline \multirow{3}{*}{$\begin{array}{l}\text { Meeting } \\
\text { management } \\
\text { score }\end{array}$} & \multicolumn{6}{|c|}{ Hospitals (Before using of six thinking hats) } & \multicolumn{6}{|c|}{ Hospitals (After using of six thinking hats) } & \multirow{3}{*}{$\boldsymbol{P}$} \\
\hline & \multicolumn{2}{|c|}{$\begin{array}{l}\text { Misr University } \\
\text { for Science and } \\
\text { Technology } \\
\text { teaching } \\
\text { hospital(n = 50) }\end{array}$} & \multicolumn{2}{|c|}{$\begin{array}{l}\text { Dar } \\
\text { el-Shefaa } \\
\text { hospital in } \\
\text { Cairo } \\
(\mathbf{n}=\mathbf{8 4})\end{array}$} & \multicolumn{2}{|c|}{$\begin{array}{l}\text { Cleopatra } \\
\text { hospital } \\
(n=76)\end{array}$} & \multicolumn{2}{|c|}{$\begin{array}{l}\text { Misr University } \\
\text { for Science and } \\
\text { Technology } \\
\text { teaching } \\
\text { hospital } \\
(n=50)\end{array}$} & \multicolumn{2}{|c|}{$\begin{array}{l}\text { Dar } \\
\text { el-Shefaa } \\
\text { hospital in } \\
\text { Cairo } \\
(\mathbf{n}=\mathbf{8 4})\end{array}$} & \multicolumn{2}{|c|}{$\begin{array}{l}\text { Cleopatra } \\
\text { hospital } \\
(n=76)\end{array}$} & \\
\hline & No. & $\%$ & No. & $\%$ & No. & $\%$ & No. & $\%$ & No. & $\%$ & No. & $\%$ & \\
\hline Low Scores & 38 & 76.00 & 79 & 94.05 & 70 & 92.11 & 0 & 0.00 & 0 & 0.00 & 0 & 0.00 & $<.001$ \\
\hline $\begin{array}{l}\text { Moderate } \\
\text { Scores }\end{array}$ & 12 & 24.00 & 5 & 5.95 & 6 & 7.89 & 7 & 14.00 & 4 & 4.76 & 3 & 3.95 & $<.001$ \\
\hline High Scores & 0 & 0.00 & 0 & 0.00 & 0 & 0.00 & 43 & 86.00 & 80 & 95.24 & 73 & 96.05 & $<.001$ \\
\hline
\end{tabular}

\section{Discussion}

Meetings are tools for accomplishing work. The work to be done can include decision making, information gathering or problem solving. Meetings are also excellent venues for recognition or celebrations. A poor use of meetings is dissemination of information or regular reports that are better suited to other means of communication. However, the present study revealed that the majority of the studied sample lack of knowledge about criteria for effective meeting as a whole, either before, during or after meeting. These findings were inconsistent with Viviane Simon-Brown et al. ${ }^{[5,21]}$ who emphasized that a successful meeting begins with good preparation, which will in turn increases the likelihood that team members will attend and actively participate, and leave feeling that something valuable was accomplished. This was supported by Eric Bowman et al. ${ }^{[3,6]}$ who asserted that the purpose of the meeting should be what the team expects to accomplish during the meeting. In other words, the meeting should have a measurable outcome. This also agreed by Ian C. et al. ${ }^{[1,4]}$ who found that meeting preparation should include determine meeting date, schedule meeting room, prepare meeting agenda, prepare meeting handouts, set-up meeting room (chairs, overhead, easel, etc.), arrange seating ensure equipment operates properly, involve the right people (whose presence is essential for achieving the purpose), and regarding time of the meeting should be the right time for participants (Start on time-end on time).

Meanwhile, regarding meeting execution, the highest percentage of the study sample were not aware of all items included in meeting execution as following the outlined activities on the agenda, keeping minutes of the meeting and applying the process techniques. These results were in contrast with Eric Bowman et al. ${ }^{[3,4]}$ who asserted that obey the code of conduct and the principles of teamwork. In addition, speaking, listening, and cooperation are the key activities of all members $n$ meeting execution. This was supported by Niki Kalemnous et al. ${ }^{[4,6]}$ who stated that setting ground rules are crucial for running an effective meeting. Council of Ontario Directors of Education ${ }^{[7]}$ added that meeting organizers, chairpersons and presenters help set the tone of the meeting. They are in the best position to ensure accessible and inclusive communication. Keeping things simple and applying a little extra attention to detail can help put all those attending the meeting at ease. This was contradicted with Ian C. \& Steve W. ${ }^{[1]}$ who advocated that a common misconception is that good results will occur simply by getting all the experts together in the same room. From researchers point's of view getting the right people together is certainly important, but that's just a first step while facilitator is crucial because he/she supports the meeting process by keeping the group on track to produce the desired objectives. This was supported by Bens et al. ${ }^{[22,23]}$ who asserted that a facilitator is someone who uses knowledge of group processes to design and deliver the structure needed for effective meetings. Facilitators can be individuals from outside the group or organization, or an internal team member or meeting leader. This also agreed by Schuman et al. ${ }^{[24,25]}$ who found that facilitator has different functions as helps group define its meeting purpose and desired objectives for a meeting, guides group discussions to keep meeting participants on track and takes notes to record key points of conversation and group decisions. 
Furthermore, regarding keeping the minutes of the meeting, Eric et al. ${ }^{[3,4]}$ mentioned that time limits are an essential part of well-run meetings. Although time limits can create anxiety, most participants will appreciate starting and ending on time more than they will resent the pressure of time limits. This was consistent with James et al. ${ }^{[1,6]}$ who stated that the first step is to map out time limitations for each activity on the agenda, to make sure each activity is given a specific amount of time that is adequate to address the issue. Finally, meeting follow-up starts before the meeting begins. During the planning stage, the meeting leader, facilitator, and planning team should discuss what type of meeting follow-up will be done and who is responsible. This will help guide the recorders at the meeting in knowing what information should be captured, to what level of detail, and in what format ${ }^{[5,6,21]}$. This was inconsistent with the present study. On the other hand Ruby et al. ${ }^{[2,4]}$ stated that short meeting summary document should be drafted within two weeks of the meeting, if possible. While, on the same line Council of Ontario Directors of Education ${ }^{[7]}$ stated that summary should contain, at a minimum, the action items and next steps, including due dates and responsible parties. James et al. ${ }^{[1,6]}$ added that formal summary reports can include background information, main points of discussion, and answers to questions asked by participants. From researchers points' of view respecting and observing deadlines and follow-up will help in achieving results from meetings. Which will in turn help to improve meeting results, this can occur by following up with each person who has an action item mid-way between meetings. Also, to achieve meeting goals, checking the progress and ensure that tasks are underway. Following meetings, each person with an action item should make a plan for their personal accomplishment of their commitment. Whether they write the steps in their planner, delegate the tasks to another person, or just complete the task, the individual is responsible for follow-up.

There are a lot of tools/techniques globally available which help to conduct or organize a good meeting. One of the most common methods of structuring the meeting is to set clear objectives, create an agenda and circulate well in advance, invite the right number and the right people, focus on the discussion point, act as a policemen (to bring back all on track) and circulate minutes of the meet with clear ownership on action points. All these techniques focus on how to conduct a structured/short meeting or how to engage everyone to discuss and focus on the agenda item. But they do not discuss on how to help structure the thinking process. There are yet some more techniques that even focus on structuring "thinking". Techniques such as "ASIT (Advanced Systematic Inventive Thinking)”, "Cause and Effect Thinking”, and another world recognized technique is "Six Thinking Hat" introduced by Sir Edward de Bono. As noticed in the present study the entire studied sample was not aware about parallel thinking, traditional thinking, lateral thinking, six thinking hats. This result was consistent with Moon et al. ${ }^{[26]}$ who found that traditional thinking methods have not changed for centuries. While these methods were powerful in dealing with a relatively stable world (where ideas and concepts tended to live longer than people), These results were in contrast with Horng et al. ${ }^{[23,27]}$ who found that this way of thinking are no longer adequate to deal with the rapidly changing world of today where new concepts and ideas are urgently needed. They also added that we need parallel thinking (Lateral thinking means thinking differently or thinking out of the box), where each thinker puts forward his/her thoughts in parallel with the thoughts of others-not attacking the thoughts of others. They actually emphasized that Six Thinking Hats method is a practical way of carrying out parallel thinking. This method is of fundamental importance because it provides us, for the first time, with a practical method of constructive thinking. This was similar to De Bono et al. ${ }^{[19,20]}$ who emphasized that Six Thinking Hat as a technique is a thinking tool for group discussion and individual thinking. Combined with the idea of parallel thinking which is associated with it, it provides a means for groups and individuals to think more effectively, and a means to plan the thinking processes in a detailed and cohesive way. On the same line Moon et al. ${ }^{[26]}$ stated that these Six different patterns in which a human brain "thinks" can be deliberately sensitized and humans can be made to think in a particular direction. This finding was supported by Mitez ${ }^{[17]}$ who asserted that six thinking hats method is extremely simple but it is powerful in its simplicity.

Regarding benefits of six thinking hats, the present study illustrated that no one of the studied sample knew them. These results were inconsistence with De Bono ${ }^{[28]}$ who stated that the six distinct states in which the brain thinks are portrayed using six different colored hats giving a particular direction to think. This was supported by De Bono et al. ${ }^{[17,19]}$ who mentioned that these are metaphorical hats and not actual physical hats that are required to be worn and changed from time to time. 
Study after study demonstrates that facilitator plays a vital role in conducting this method successfully. This was in contrast with the present study. It was noticed that no one was aware of the facilitator's role in conducting six thinking hats technique. While Higher Education Funding Council for England ${ }^{[29]}$ emphasized that facilitator plans the sequence and timing of the thinking and ask for changes in the thinking if needed and facilitator forms periodic or final summaries of the thinking for consideration by the team. In respect to the role of the participants, the present study revealed that also no one was aware of their roles. This is consistent with Mangena and Chabelli, M. ${ }^{[30]}$ who found that participants follow the lead of six thinking hats facilitator and stick to the hat (type of thinking) that is in current use. This finding was supported by Mevlüde et al. ${ }^{[20]}$ asserted that participants try to work within the time limits and contribute honestly and fully under each of the hats.

It was interesting that the present study revealed that all of studied sample agreed upon using of six thinking hats in meetings. These findings were consistent with Mitez ${ }^{[17]}$ who noted that using of six thinking hats in meetings helps to engage and empower all stakeholders and save time by organizing thinking. These findings were similar to that of Seymour et al. ${ }^{[19,31]}$ who advocated that it encourages diversity of thought and it can be used when change is necessary and resistance to change is likely. This was supported by Gonzalez et al. ${ }^{[2,27,32]}$ who stated that it improves creativity and innovation, foster collaborative thinking, provides a common language and helps people work against type, preference. This also agreed by Jasper et al. ${ }^{[8,33]}$ who found that it helps in removal of ego from decisions (reduce confrontation) and allows a switch in thinking without threatening ego.

For many organizations, meetings are a way of life. Clearly, making these meetings as productive as possible goes a long way toward increasing organizational productivity. Regarding study sample's evaluation of meeting management after using of six thinking hats, the majority of them had high score. These findings were consistent with Ruby and Niki ${ }^{[2,4]}$ who found that six thinking hats is a process that helps facilitate focused, successful and end in the correct decision making meeting. On the same line James et al. ${ }^{[6,17]}$ stated that using six thinking hats encouraging various perspectives, including creativity, knowledge, optimism, realism, etc. this concept will help boost the success of meetings. All of these were similar to the present study. These results were consistence with De Bono ${ }^{[19]}$ who believed that the key to a successful use of the six think hats methodology was the deliberate focusing of the discussion on a particular approach as needed during the meeting or collaboration session.

\section{Conclusion}

According to the study findings, it was concluded that the majority of the study sample before awareness session were lack knowledge about criteria for effective meeting and six thinking hats. There was a high significant $(p<.001)$ difference between them before and after awareness sessions. Also, the majority of them agreed upon all of items regarding using of six thinking hats in meetings post training. Finally, study sample's evaluation of meeting management scores before using of six thinking hats was low.

\section{Recommendations}

\section{Based on the study findings, the following recommendations were suggested:}

1. Crucial interest should be given by universities, faculties, hospitals and even in all organizations to the Six Thinking Hats technique as it promotes meetings' outcomes.

2. Using six thinking hats in different areas of nursing, because literature on six thinking hats has been more focused on educational areas, with a lack of studies on the nursing field. 


\section{References}

[1] Ian C. \& Steve W. A Useful Guide to Managing Meetings. Pansophix. 2008: 1-30.

[2] Ruby LingleLocal. LOCAL GOVERNMENT TOPICS. Effective Meeting Management. Government Information and Education Network of the University of Illinois Extension Service (LGIEN). 2002.

[3] Eric Bowman. How to Hold Effective Meetings. Cooperative Starter Series. 2006).

[4] Niki Kalemnous. Professional Meeting Management, a guidebook for those interested in the meeting and event industry. 2009.

[5] David Driskill. Effective Meeting Management A Brief Guide for Facilitators, Presenters \& Participants. NQR Institute. 2004.

[6] James H. Saylor. Conducting Effective Meetings Workbook. U.S.A. Managing for VICTORY. 2006: 1-36.

[7] Council of Ontario Directors of Education. Effective Meeting Management. Advisory 2011; (8).

[8] Jasper, M. Professional Development, Reflection and Decision-Making. Oxford: Blackwell Publishing Ltd. 2006.

[9] Goebel, G. and Seabert, D. Put on your thinking hats. Journal of School Health. 2006; 76(7):393-395. PMid:16918874 http://dx.doi.org/10.1111/j.1746-1561.2006.00131.x

[10] De Bono, E. “Serious creativity”, Journal for Quality \& Participation, 1995; 18(5).

[11] Wang, J., Lo, C. K., Chen, K., Shieh, J., \& Ku, Y. The efficacy of teaching by professional nursing concept utilizing problem solving strategies for students enrolled in a 2-year baccalaureate nursing program. The Journal of Nursing Research. 2002; 10(2): 113-119. PMid:12119596 http://dx.doi.org/10.1097/01.JNR.0000347590.36144.bd

[12] Lewis, D. Clinical supervision for nurse lecturers. Nursing Standard. 1998; 12(29): 40-43. PMid:9625004

[13] De Bono, E. Lateral Thinking. Penguin Books, Ward Lock Education. 1970.

[14] Kenny, L. Using Edward De Bono's six hats game to aid critical thinking and reflection in palliative care. International Journal of Palliative Nursing. 2003; 9(3):105-112. PMid:12682572

[15] Sally, B. Six hat supervision: a model for the supervisor of midwives. British Journal of Midwifery. 2008; 16(11): 736-742.

[16] Karadag, M., Saritas, S., \& Erginer, E. Using the "six thinking hats”model of learning in a surgical nursing class: sharing experience and student opinions. Australian Journal of Advanced Nursing. 2009; 26(3): 59-69.

[17] Mitez S. Six Thinking Hats. Asian Journal of Management Research. 2012;2(2): 814-820.

[18] Kenny, L. Using Edward de Bono"s six thinking hats game to aid critical thinking and reflection in palliative care. International Journal of Palliative Nursing. 2003; 9(3): 105-112.

[19] De Bono, E. Edward de Bono’s thinking Course: Powerful Tools to Transform Your Thinking. London: British Broadcasting Corporation. 2009. PMid:12682572

[20] Mevlüde K., Serdar S. \& Ergin E. Using the ‘six thinking hats' model of learning in a surgical nursing class: sharing the experience and student opinions. Australian Journal of Advanced Nursing. 2009; 26(3): 59-69.

[21] Viviane Simon-Brown. Effective Meetings Management. Oregon State University. 1999; 1-12.

[22] Bens, Ingrid. Facilitating with Ease! Core Skills for Facilitators, Team Leaders and Members, Managers, Consultants, and Trainers. 2nd Edition. Jossey-Bass. San Francisco, CA. 2005.

[23] Kaner, Sam, Lenny Lind, Catherine Toldi, Sarah Fisk, and Duane Berger. The Facilitator’s Guide to Participatory Decision-Making. 2nd Edition. Jossey-Bass. San Francisco, CA. 2007.

[24] Schuman, Sandy (editor). The IAF Handbook of Group Facilitation: Best Practices from the Leading Organization in Facilitation. Jossey-Bass. San Francisco, CA. 2005.

[25] Schwartz, Roger, Anne Davidson, Peg Carlson, and Sue McKinney. The Skilled Facilitator Fieldbook: Tips, Tools, and Tested Methods for Consultants, Facilitators, Managers, Trainers, and Coaches. Jossey-Bass. San Francisco, CA. 2005.

[26] Moon, B., Hoffman,R.R., and Canas,A. Applied Concept Mapping: Capturing, Analyzing, and Organizing Knowledge. Boca Raton, FL: CRC Press.2011.

[27] Horng, J., Hong, J., Chanlin, L., Chang, S. and Chu, H. Creative teachers and creative teaching strategies. International Journal of Consumer Studies. 2005; 29(4):352-358. http://dx.doi.org/10.1111/j.1470-6431.2005.00445.x

[28] De Bono, E. Six Thinking Hats. Penguin, London. 2000.

[29] Higher Education Funding Council for England. Annex A Initial decisions on the Research Excellence Framework. HEFCE, Bristol. 2010.

[30] Mangena, A. and Chabelli, M. Strategies to overcome obstacles in the facilitation of critical thinking in nursing education. Nurse Education Today. 2005; 25(4): 291-298. PMid:15896414 http://dx.doi.org/10.1016/j.nedt.2005.01.012

[31] Seymour, B., Kinn, S. and Sutherland, N. Valuing both critical and creative thinking in clinical practice: narrowing the research practice gap? Journal of Advanced Nursing. 2003; 42(3): 288-296. PMid:12680973

http://dx.doi.org/10.1046/j.1365-2648.2003.02618.x 
[32] Gonzalez, D. The Art of Solving Problems: Comparing the Similarities and Differences Between Creative Problem Solving, Lateral Thinking and Synectics. New York: International Center for Studies in Creativity. 2001.

[33] McGregor, D. Developing Thinking: Developing Learning: A Guide to Thinking Skills. London: Library of Congress cataloguing-in- Publication Data CIP data. 2007.

[34] Yasuhisa Tamura, Shuichi Furukawa CSCL Environment for “Six Thinking Hats”Discussion. KES (3). 2007; 583-589. 